\title{
Nell-1 Enhances Osteogenic Differentiation of Pre-Osteoblasts on Titanium Surfaces via the MAPK-ERK Signaling Pathway
}

\author{
Mei-jie Shen ${ }^{a, b} \quad$ Ge-ge Wang ${ }^{a} \quad$ Yu-zhen Wang ${ }^{a} \quad$ Jing Xie $^{a} \quad$ Xi Ding ${ }^{a}$ \\ aDepartment of Stomatology, the First Affiliated Hospital of Wenzhou Medical University, Wenzhou, \\ bDepartment of Stomatology, the First People's Hospital of Tongxiang, Jiaxing, China
}

\section{Key Words}

Titanium (Ti) surface $・$ Pre-osteoblasts $・$ Nell-1 1 MAPK/ERK signaling pathway

\begin{abstract}
Background/Aims: This study aimed to investigate the effect of Nell-1 on the osteogenic behaviors of pre-osteoblasts on titanium (Ti) surfaces and to identify the underlying signaling pathway. Methods: Nell-1 at different concentrations was added to culture medium to stimulate MC3T3-E1 subclone 14 on Ti surfaces. A CCK-8 colorimetric assay was used to detect cell proliferation. Alkaline phosphatase activity (ALP) assay and enzyme-linked immunosorbent assay (ELISA) were used to evaluate ALP activity and the osteocalcin (OCN) secretion, respectively. Indicators of osteoblastic differentiation were assessed using real-time polymerase chain reaction analysis (RT-PCR). Western blot (WB) assay was used to analyze the expression changes of the osteogenic proteins and the mitogen-activated protein kinase (MAPK) pathway. Results: Nell-1 significantly increased the osteogenic gene and protein expression levels of ALP, OCN, Runx2, osteoprotegerin (OPG), collagen type I (Col-I), and Osterix (Osx) in pre-osteoblasts on Ti surfaces. The optimal concentration of Nell-1 was $100 \mathrm{ng} /$ ml. In addition, Nell-1 activated ERK and JNK, but not P38, in MC3T3-E1 cells on the Ti surface. Except for ALP and Col-I, the promotive effects of Nell-1 on the expression of osteogenic markers were suppressed by ERK inhibitor U0126. Conclusion: Certain concentrations of Nell1 can promote the osteogenic differentiation of pre-osteoblasts on Ti surfaces by activating the MAPK/ERK signaling pathway.
\end{abstract}

(C) 2018 The Author(s)

Published by S. Karger AG, Basel

\section{Introduction}

Titanium (Ti) is one of the most commonly used materials for dental implants. Surface modification plays an important role in Ti implants' special physical morphology, chemical composition, and biochemical modifications, which promote the adhesion, proliferation and differentiation of osteoblasts on Ti surfaces; as a result, the bone integration cycle can be 


\section{Cellular Physiology Cell Physiol Biochem 2018;50:1522-1534

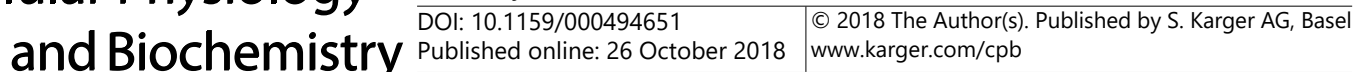

shortened, and bone-bonding strength is enhanced [1-5]. Esposito $\mathrm{M}$ et al. analyzed various factors associated with the success of osseointegrated dental implants based on the findings of clinical trials and concluded that the initial adhesion of cells determines the final fate of osteoblasts on the implant surface [6]. The early adhesion of osteoblasts to the tissueimplant interface is of great significance for the osteointegration and final success of the implants because it largely determines whether the bond between a dental implant and bone tissue will be long lasting.

Cytokine-based therapy for the osteointegration of implants has attracted considerable attention from researchers due to its strong ability to regulate cellular functions. Nell1, a unique Nel-like secreted protein consisting of 810 amino acids, was first isolated and characterized in craniosynostosis patients, and it was found to be upregulated within prematurely fusing sutures [7]. Transgenic mice overexpressing the Nell-1 gene showed a phenotype similar to that of human craniosynostosis, while Nell-1-deficient mice exhibited cranial and vertebral bone defects, suggesting an important role of Nell-1 in skeletal development $[8,9]$. Mechanistically, Nell-1 binds to the cell membrane receptor integrin b1[10] and regulates the activity of the master osteogenic transcription factor, Runt-related transcription factor 2 (Runx2) [11]. In recent years, the role of Nell-1 in the potent induction of bone development has been confirmed in in vivo models $[12,13]$. As an effective growth factor, Nell-1 is very specifically associated with the osteochondral lineage; thus, it has higher bio-safety and accuracy for treating bone defects and enhancing bone regeneration compared with bone morphogenetic proteins (BMPs) $[14,15]$. Studies have demonstrated that overexpression of Nell-1 via adenovirus infection led to upregulated expression of osteogenic genes, including osteopontin (OPN) and osteocalcin (OCN), in MC3T3-E1 preosteoblasts [16]. Although the osteogenic effects of Nell-1 have been clearly elucidated [16-19], the effects of Nell-1 on the growth, function and mechanism of MC3T3-E1 preosteoblasts, particularly MC3T3-E1 cells cultured on Ti, remain unclear.

There are four main molecular pathways involved in osteogenesis, i.e., the BMP-Smads pathway, the Wnt/ $\beta$-catenin pathway, the mitogen-activated protein kinase (MAPK) pathway and the Notch pathway. They coordinate and interact with one another and play an important role in the proliferation and differentiation of osteoblasts. The MAPK signaling pathway is involved in controlling cell growth, development, division, death and other physiological sub-activity processes by influencing nuclear transcription factors [20]; additionally, the MAPK signaling pathway plays a pivotal role in the activation and signaling of various growth factors [21-24]. One of the most thoroughly studied MAPK family members, extracellular signal-regulated kinase (ERK), is extensively expressed in cells and involved in the regulation of a series of life-cycle processes, including meiosis, cell differentiation, mitosis, and energy metabolism [25]. The study by Bokui $\mathrm{N}$ et al. revealed that the ERK signaling pathway may play a role in the Nell-1-induced osteoblastic differentiation of primary rat embryonic cranial cells (RFC) [26]. This prompted us to further explore the role of the MAPK-ERK signaling pathway in the Nell-1-induced osteoblastic differentiation of MC3T3-E1 pre-osteoblasts on Ti surfaces.

Here, we explore the roles of Nell-1 in activating pre-osteoblasts on Ti surfaces and seek to clarify the regulatory role of ERK-MAPK in the Nell-1-induced osteogenic behavior of MC3T3-E1 pre-osteoblasts on Ti surfaces.

\section{Materials and Methods}

\section{Biomaterials}

Pure Ti disks with dimensions of $22 \mathrm{~mm}$ and $34 \mathrm{~mm}$ were machined to fit into 12-well plates and 6-well plates, respectively. They were polished using \#400, \#600, \#800 and \#1200 sand paper consecutively; blasted with white corundum sand at 0.8 pressure; cleaned ultrasonically in acetone, absolute ethyl alcohol and ultrapure water; passivated with $40 \%$ nitric acid for $30 \mathrm{~min}$; and then ultrasonically cleaned with 


\section{Cellular Physiology Cell Physiol Biochem 2018;50:1522-1534 \begin{tabular}{ll|l} 
and Biochemistry 10.1159/000494651 & $\begin{array}{l}\text { O 2018 The Author(s). Published by S. Karger AG, Basel } \\
\text { Published online: 260ctober } 2018 \text { wwarger.com/cpb }\end{array}$ \\
\cline { 2 - 3 }
\end{tabular}

distilled water and dried at room temperature. Prior to use, all disks were disinfected with ultraviolet irradiation for $30 \mathrm{~min}$.

Bioactive recombinant human Nell-1 protein (rhNell-1) was produced and purified from Chinese hamster ovary cells (R\&D Systems, USA).

Cell osteoblast culture and cell seeding

The mouse osteoblastic MC3T3-E1 subclone 14 cell line was purchased from the Type Culture Collection of the Chinese Academy of Sciences, Shanghai, China (ATCC CRL-2594). MC3T3-E1 cells were cultured in a-MEM (Gibco, USA) supplemented with 10\% fetal bovine serum (FBS, Gibco, USA), 1\% penicillin/streptomycin (Sigma-Aldrich Corp, USA), and $2 \mathrm{mM}$ L-glutamine (Gibco, USA) and incubated in a $5 \% \mathrm{CO}_{2}$ atmosphere at $37^{\circ} \mathrm{C}$.

The cells were seeded at a density of 20, 000 cells per $\mathrm{ml}$ in the 12 -well plates and 50, 000 cells per $\mathrm{ml}$ in the 6-well plates. The Ti disks with treated and disinfected surfaces were placed at the bottom of the plates. Osteoblastic differentiation was induced in $\alpha$-MEM containing $10 \mathrm{mM} \beta$-glycerophosphate, $0.1 \mu \mathrm{M}$ dexamethasone and $0.05 \mathrm{mM}$ ascorbic acid.

\section{Inhibition of the MAPK/ERK signaling pathway}

U0126, an ERK/MAPK inhibitor, was purchased from MedChem Express (MCE, USA). MC3T3-E1 preosteoblasts were pre-incubated with U0126 at a concentration of $5 \mu \mathrm{M}$ for $1 \mathrm{~h}$ and then incubated in basal medium or differentiation medium with the inhibitor for 6 to 18 days according to the requirements of each experiment.

\section{Cell viability assay}

MC3T3-E1 pre-osteoblasts were seeded on the Ti disks in a 12-well plate. After $24 \mathrm{~h}$, the cells were divided into five groups and incubated with Nell-1 at concentrations of $0 \mathrm{ng} / \mathrm{m}, 1 \mathrm{ng} / \mathrm{ml}, 10 \mathrm{ng} / \mathrm{ml}, 100 \mathrm{ng} /$ $\mathrm{ml}$, or $500 \mathrm{ng} / \mathrm{ml}$ at $37^{\circ} \mathrm{C}$. On day 1,3 or 5 , the culture medium in each well was replaced with $10 \%$ CCK- 8 buffer, the cells were incubated for another $2 \mathrm{~h}$ and then subjected to a CCK-8 colorimetric assay for cell viability assessment. The solution sample $(200 \mu \mathrm{l})$ from each well was transferred in triplicate into a 96 well plate, and its absorbance was measured at a wavelength of $450 \mathrm{~nm}$ by a spectrophotometer. The mean reading of each triplication was used for the analysis, and the experiment was repeated three times.

\section{Alkaline phosphatase activity assay}

Alkaline phosphatase (ALP) activity was measured using an ALP activity assay kit (Wako Pure Chemical Industries, Ltd., 1-2, Doshomachi 3-Chome, Chuo-Ku, Osaka, Japan). The MC3T3-E1 pre-osteoblasts cultured in 6-well plates were lysed with $80 \mu \mathrm{l}$ of cell lysis reagent (Sigma-Aldrich, St Louis, MO, USA) and then the lysate was normalized for total cellular protein content using a BCA protein assay kit (Thermo, Rockford, IL, USA). After reaction with p-nitrophenol phosphate (pNPP) substrate, the OD values of the standards and samples were measured at a wavelength of $405 \mathrm{~nm}$ according to the manufacturer's instructions to evaluate the ALP activity level. The experiment was repeated three times in quadruplicate wells.

\section{Enzyme-linked immunosorbent assay (ELISA) for} OCN expression

The supernatant in each well of the 6-well plates was collected and stored in a refrigerator at $80^{\circ} \mathrm{C}$ prior to OCN quantification. The OCN levels were determined using commercially available mouse-specific ELISA kits (R\&D Systems, USA). The absorbance at a wavelength of $450 \mathrm{~nm}$ was measured using a microplate reader. The results were normalized according to the total cellular protein content determined with a BCA protein assay kit and expressed as ng/mg protein.
Table 1. Primer sequences for real-time PCR

\begin{tabular}{lc}
\hline Gene & Sequences \\
\hline \multirow{2}{*}{ Runx2 } & forward: 5-CCCGTGGCCTCAAGGT-3 \\
& reverse: 5-CGTTACCCGCCATGACAGTA-3 \\
COL-I & forward:5-ATGCCGCGACCTCAAGATG-3 \\
& reverse: 5-TGAGGCACAGACGGCTGAGTA-3 \\
OCN & forward: 5-AGCAGCTTGGCCCAGACCTA-3 \\
& reverse: 5-TAGCGCCGGAGTCTGTTCACTAC-3 \\
OSX & forward:5-TGGTACACGGCAGGCATCCA-3 \\
& reverse: 5-GGAGCAACGTCAGATGGGTAAGT-3 \\
ALP & forward:5-TGCATGAATTCCCTGCCTTACCAACTCATTT-3 \\
& reverse: 5-TGCATAAGCTTGAGAGCCACAAAGGGAACT-3 \\
OPG & forward:5-CAGAGAAGCCACGCAAAAGTG-3 \\
& reverse: 5-AGCTGTGTCTCCGTTTTATCCT-3 \\
GAPDH & forward: 5-TGTGTCCGTCGTGGATCTGA-3 \\
& reverse: 5-TTGCTGTTGAAGTCGCAGGAG-3 \\
\hline
\end{tabular}




\section{Cellular Physiology Cell Physiol Biochem 2018;50:1522-1534 \begin{tabular}{ll|l} 
DOl: 10.1159/000494651 & $\begin{array}{l}\text { O } 2018 \text { The Author(s). Published by S. Karger AG, Basel } \\
\text { www.karger.com/cpb }\end{array}$ \\
\hline
\end{tabular}}

\section{Western blot (WB) assay}

The MC3T3-E1 pre-osteoblasts cultured in 6-well plates to subconfluence were stimulated with Nell-1 at concentrations of $0 \mathrm{~g} / \mathrm{m}, 1 \mathrm{ng} / \mathrm{ml}, 10 \mathrm{ng} / \mathrm{ml}, 100 \mathrm{ng} / \mathrm{ml}$, or $500 \mathrm{ng} / \mathrm{ml}$. Cellular proteins were extracted using RIPA lysis buffer (Sigma-Aldrich) and quantified using a BCA protein assay kit. After protein separation on a $10 \%$ SDS-PAGE gel, the sample was transferred to a PVDF membrane (Bio-Rad, Hercules, CA, USA). After blocking with $5 \%$ fat-free milk, the membrane was incubated overnight at $4{ }^{\circ} \mathrm{C}$ with the following primary antibodies: osteoprotegerin (Cat.ab9986, Abcam), Collagen I (Cat.ab34710, Abcam), Runx2 (Cat.8486, Cell Signaling), Phospho-ERK1/2 (Cat.4370, Cell Signaling), ERK1/2 (Cat.4695, Cell Signaling), Phospho-SAPK/ JNK (Cat.4668, Cell Signaling), SAPK/JNK (Cat.9252, Cell Signaling), Phospho-P38 (Cat.4511, Cell Signaling), P38 (Cat.8690, Cell Signaling), or GAPDH. Except for anti-Phospho-ERK1/2 antibody, which was used at a dilution of 1:2000, all primary antibodies were used at 1:1000 dilution. The following morning, the membrane was incubated with the corresponding secondary HRP-conjugated antibodies for $1 \mathrm{~h}$ at room temperature and then exposed to an ECL reagent (Super Signal, Pierce, Rockford, IL, USA). The signals were viewed and analyzed using the ChemiDicTM XRS+ imaging system (Bio-Rad Laboratories, Hercules, CA, USA), and the band densities were quantified with Image Lab software (BioRad). Each test was repeated at least three times.

\section{Real-time PCR}

MC3T3-E1 pre-osteoblasts in 6-well plates were washed three times with PBS and lysed with TRIzol reagent (TriPure Isolation Reagent, Roche Applied Science). Total RNA was extracted according to the manufacturer's protocol. The extracted RNA was quantified with UV spectrophotometry, and only samples with a ratio of absorbance at 260 and $280 \mathrm{~nm}$ (the 260/280 ratio) greater than 1.8 were used in the subsequent steps. Total RNA $(0.5 \mu \mathrm{g})$ was reverse transcribed in duplicate, and another RNA sample incubated without reverse transcriptase was used as the control (noRT control). The PrimeScript RT reagent kit was used for cDNA synthesis, and a MyCycler TM thermocycler (Bio-Rad, USA) was used for polymerase chain reaction (PCR). All primers used are listed in Table 1. Samples were run in parallel with each primer set in real-time PCR with bio-radiQ SYBR® Green Super Mix. Each step was repeated at least three times.

\section{Statistical analysis}

The results were analyzed using SPSS software (SPSS 21, Chicago, IL, USA). The data are presented as means $\pm \mathrm{SD}$; at least three independent experiments were performed for each test. Differences between groups were assessed with Student's $t$-test and one-way analysis of variance. $P$ values $<0.05$ were considered statistically significant.

\section{Results}

Ti surface characteristics and growth of MC3T3-E1 pre-osteoblasts

The processed Ti surface presented an uneven and rough morphology in SEM images (Fig. 1A). At $24 \mathrm{~h}$ after seeding, MC3T3-E1 cells were attached to the Ti surface and well dispersed. Moreover, the cells developed polygonal membranes and showed the morphological characteristics of pre-osteoblasts (Fig. 1B).

Fig. 1. Representative scanning electron microscope (SEM) images at a magnification of $\times 2000$. A: Surface morphology of the Ti disks. B: Preosteoblasts attached to a Ti surface after $24 \mathrm{~h}$

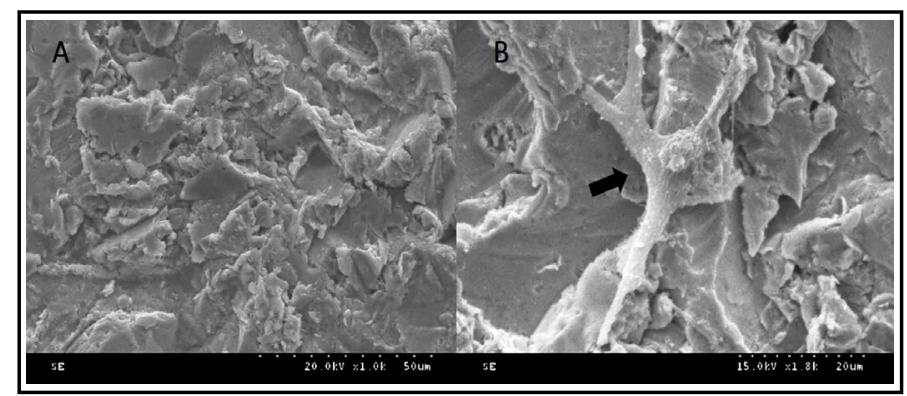




\section{Cellular Physiology Cell Physiol Biochem 2018:50:1522-1534

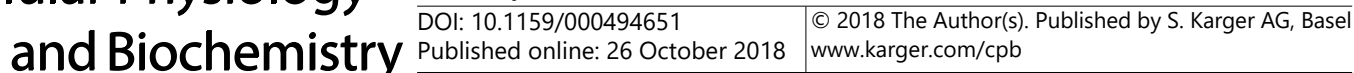

Fig. 2. Effect of Nell-1 on the proliferation of MC3T3-E1 pre-osteoblasts cultured on Ti surfaces. Treatment with Nell-1 at all concentrations (0-500 $\mathrm{ng} / \mathrm{ml}$ ) decreased the proliferation of MC3T3-E1 cells on Ti surfaces from day 1 to day 5 in a time-dependent manner. Data represent the mean \pm SD (bars) of three independent experiments; ${ }^{*} \mathrm{P}<0.05$, ${ }^{* *} \mathrm{P}<0.01^{*}$ compared with the $0 \mathrm{ng} / \mathrm{ml}$ Nell-1 treatment group (control group).

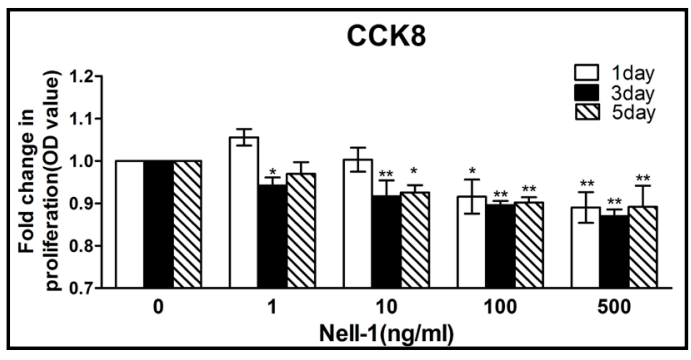

Fig. 3. Effect of Nell-1 on the ALP activity of MC3T3-E1 pre-osteoblasts cultured on Ti surfaces. Cells cultured in basal medium or differentiation medium containing different concentrations of Nell-1 (0-500 ng/ml) were monitored for ALP activity. The results at days 4,8 and 12 showed that ALP activity in the cells was enhanced by Nell1 and was highest in the $100 \mathrm{ng} / \mathrm{ml}$ group on the $8^{\text {th }}$ day. Data represent the mean \pm SD (bars) of three independent experiments; ${ }^{*} \mathrm{P}<0.05$, ${ }^{* *} \mathrm{P}<0.01$

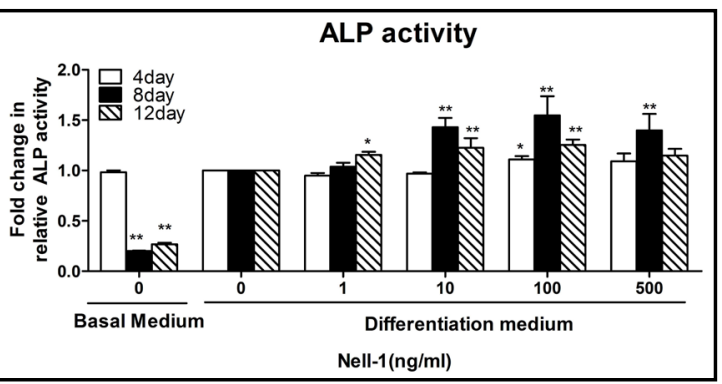
compared with the cells cultured in differentiation medium containing $0 \mathrm{ng} / \mathrm{ml} \mathrm{Nell}-1$.

Fig. 4. Effect of Nell-1 on osteocalcin expression in MC3T3-E1 pre-osteoblasts cultured on Ti surfaces. Cells cultured in basal medium or differentiation medium containing different concentrations of Nell-1 (0-500 ng/ml) were monitored for OCN expression. The results at days $6,12,18$, and 24 showed that OCN expression in the cells was enhanced by Nell-1, and expression was highest in the $100 \mathrm{ng} / \mathrm{ml}$ group on the $18^{\text {th }}$ day. Data represent

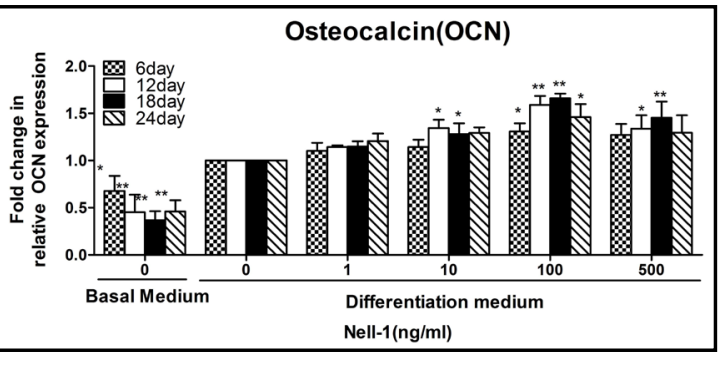
the mean \pm SD (bars) of three independent experiments; ${ }^{*} \mathrm{P}<0.05,{ }^{*} \mathrm{P}<0.01$ compared with cells cultured in differentiation medium containing $0 \mathrm{ng} /$ ml Nell-1.

Nell-1 suppressed the proliferation but enhanced the osteogenesis of MC3T3-E1 preosteoblasts on the Ti surface

The proliferation of MC3T3-E1 pre-osteoblasts was assessed with a CCK-8 assay. The proliferation activity of the cells treated with 10,100 and $500 \mathrm{ng} / \mathrm{ml}$ Nell-1 was significantly lower than that of the control group on the Ti surfaces, suggesting that Nell-1 suppressed the proliferation of MC3T3-E1 pre-osteoblasts in a dose-dependent manner (Fig. 2). Early osteogenesis is characterized by increased ALP activity. In this study, after Nell-1 treatment, the ALP activity of MC3T3-E1 cells attached to the Ti surface increased remarkably from day 4 to day 8 and then decreased between days 8 and 12. In particular, Nell- 1 at concentrations of 10 and $100 \mathrm{ng} / \mathrm{ml}$ significantly enhanced the ALP activity of the cells. The most prominent change occurred on post-treatment day 8 in the cells treated with $100 \mathrm{ng} / \mathrm{ml} \mathrm{Nell}-1(P<0.05)$ (Fig. 3). Next, the expression of OCN, an osteogenic marker of later stages of osteogenesis, was tested. The results showed that OCN expression increased from day 6 to day 18 and then declined from day 18 to day 24. On days 12 and 18, OCN expression in the cells treated with 10 and $100 \mathrm{ng} / \mathrm{ml} \mathrm{Nell-1}$ was significantly higher than that of the control group in differentiation media $(P<0.05)$, with the highest expression occurring on day 18 in the $100 \mathrm{ng} / \mathrm{ml} \mathrm{Nell-1}$ treatment group (Fig. 4). Additionally, after 6 days of Nell-1 stimulation, the expression of Runx2, osteoprotegerin (OPG), and collagen type I (Col-I) significantly 
Fig. 5. Nell-1-induced increases in osteogenic protein expression in MC3T3-E1 pre-osteoblasts cultured on Ti surfaces. Representative Western blots (A) showed that the expression levels of Runx2, OPG, and Col-I in the pre-osteoblasts increased after treatment with Nell-1 for six days. Western blot analysis showed similar patterns of change for Runx2 (B), OPG (C) and Col-I (D) protein expressions with the increased dose of Nell-1. Data represent the mean \pm SD (bars) of three independent experiments; $* \mathrm{P}<0.05$, ${ }^{* *} \mathrm{P}<0.01$ compared with cells cultured in differentiation medium containing 0 $\mathrm{ng} / \mathrm{ml}$ Nell-1.

Fig. 6. Nell-1-induced changes in the mRNA expression levels of osteogenic markers in MC3T3-E1 pre-osteoblasts cultured on Ti surfaces. Real-time PCR analysis demonstrated similar patterns of change in ALP (A), OCN (B), Runx2 (C), Col-I (D), OPG (E) and Osx (F) gene expression with the increased dose of Nell-1 at day 6, indicating that $100 \mathrm{ng} /$ $\mathrm{ml}$ was the most effective dose. Data represent the mean \pm SD (bars) of three independent experiments; $* \mathrm{P}<0.05$, ${ }^{* *} \mathrm{P}<0.01$ compared with cells cultured in differentiation medium containing 0 $\mathrm{ng} / \mathrm{ml}$ Nell-1.
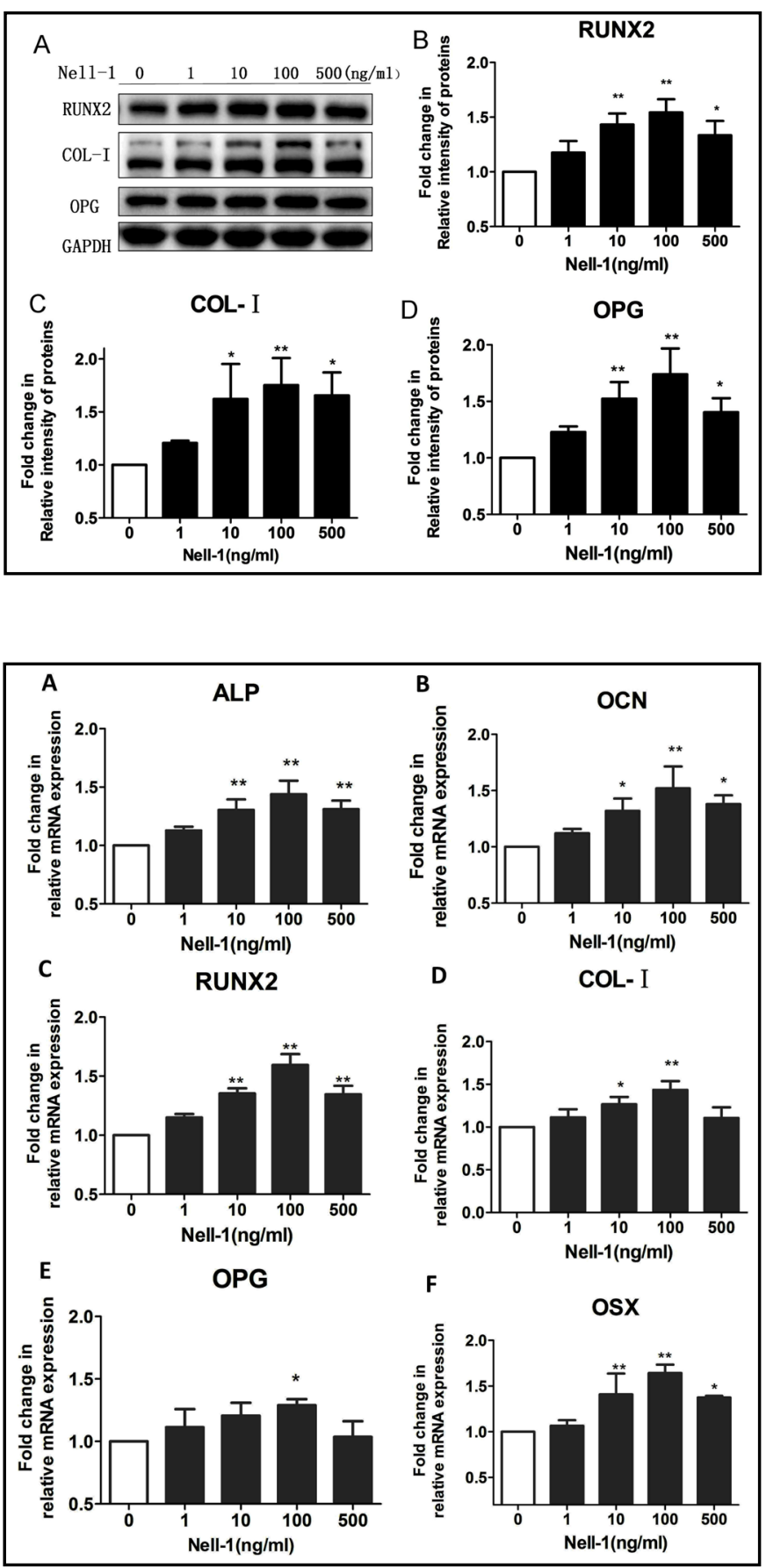

increased in cells treated with 10, 100 and $500 \mathrm{ng} / \mathrm{ml}$ Nell-1 compared with the control group, with the most prominent increase occurring in the $100 \mathrm{ng} / \mathrm{ml}$ Nell-1 treatment group $(P<0.01)$ (Fig. 5).Consistent with these results, real-time PCR analysis demonstrated that the mRNA expression levels of all the detected osteogenic markers, including ALP, OCN, Runx2, OPG, Col-I and Osterix (Osx), in MC3T3-E1 pre-osteoblasts were upregulated after Nell-1 treatment and were highest in the $100 \mathrm{ng} / \mathrm{ml}$ Nell-1 group compared with the control group (Fig. 6). 
Fig. 7. Increase in ERK and JNK phosphorylation in pre-osteoblasts treated with Nell-1. MC3T3-E1 cells were cultured in serum-free medium on Ti surfaces for $4 \mathrm{~h}$ and then treated with Nell- 1 at different concentrations for $1 \mathrm{~h}$. Panel (A) shows the representative Western blots of $\mathrm{p}$-JNK, JNK, p-ERK, ERK, p-P38 and P38 in the pre-osteoblasts after treatment with Nell-1 at concentrations of 0-500 ng/ $\mathrm{ml}$ for six days. Western blot analysis of p-JNK and p-ERK shows that Nell1 enhanced the phosphorylation of JNK (B) and ERK (C) but suppressed P38 phosphorylation. GAPDH was used as an internal control, and the

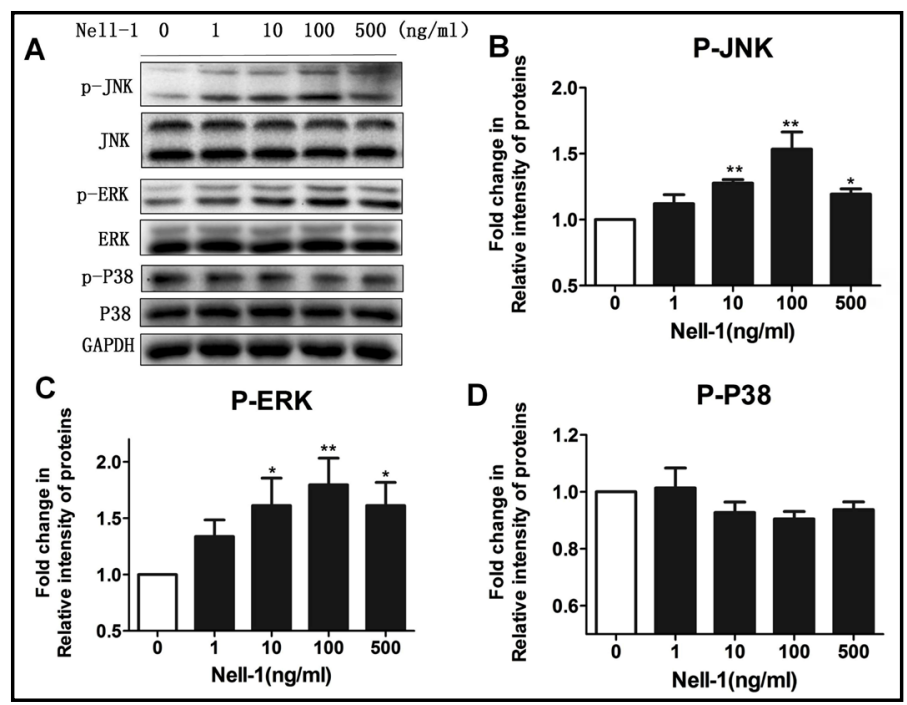
expression levels of phosphorylated JNK, ERK and P38 were normalized to those of total JNK, ERK and P38, respectively. Data represent the mean \pm SD (bars) of three independent experiments; ${ }^{*} \mathrm{P}<0.05$, ${ }^{* *} \mathrm{P}<0.01$ compared with cells cultured in differentiation medium containing $0 \mathrm{ng} / \mathrm{ml}$ Nell-1.

Fig. 8. A: Promotive effect of U0126 on Nell-1-induced changed in the ALP activity of MC3T3-E1 pre-osteoblasts on Ti surfaces. Cells were cultured in basal medium or differentiation medium containing $100 \mathrm{ng} / \mathrm{ml}$ Nell-1 with or without the addition of $5 \mu \mathrm{M} \mathrm{U} 0126$ on day 8. B: Suppression of Nell-1enhanced OCN expression in MC3T3-E1
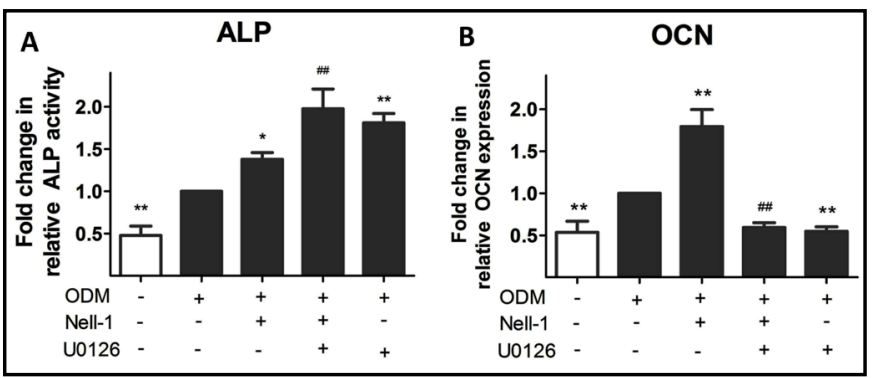
pre-osteoblasts on $\mathrm{Ti}$ surfaces. Cells were cultured in basal medium or differentiation medium containing $100 \mathrm{ng} / \mathrm{ml} \mathrm{Nell}-1$ with or without the addition of $5 \mu \mathrm{M}$ U0126 on day 18. Data represent the mean \pm SD (bars) of three independent experiments; ${ }^{*} \mathrm{P}<0.05,{ }^{* *} \mathrm{P}<0.01$ compared with cells cultured in differentiation medium containing $0 \mathrm{ng} / \mathrm{ml} \mathrm{Nell}-1$.

Nell-1 activated ERK and JNK in MC3T3-E1 pre-osteoblasts on the Ti surface

The activation of ERK, p38, and JNK in MC3T3-E1 cells cultured in serum-free $\alpha$-MEM on the Ti surface were examined after $1 \mathrm{~h}$ of Nell-1 stimulation. WB assays showed that while no remarkable change in P38 phosphorylation was detected, the phosphorylation of JNK and ERK in MC3T3-E1 cells was significantly enhanced by Nell-1, particularly by $100 \mathrm{ng} / \mathrm{ml} \mathrm{Nell-}$ 1, compared with the control groups $(P<0.05)$ (Fig. 7).

\section{U0126 inhibited Nell-1-promoted osteoblast differentiation}

To further verify the relationship between Nell-1 and ERK activation and elucidate the role of Nell-1 in promoting ALP activity in pre-osteoblasts, U0126 (5 $\mu \mathrm{M})$, an ERK inhibitor, was used to pretreat the MC3T3-E1 cells 8 days before treatment with Nell-1 at the concentration of $100 \mathrm{ng} / \mathrm{ml}$. The results showed that ALP activity in the cells that were pretreated with U0126 and then treated with $100 \mathrm{ng} / \mathrm{ml}$ Nell-1 increased compared to the unpretreated control cells (Fig. 8B). However, the MC3T3-E1 cells treated with U0126 alone also showed significantly upregulated ALP activity; consequently, the evidence regarding 
Fig. 9. Effect of U0126 on Nell-1-induced changes in p-ERK, Runx2, OPG and Col-I protein expression in MC3T3-E1 preosteoblasts on Ti surfaces. Cells were treated with or without $100 \mathrm{ng} / \mathrm{ml}$ Nell-1 plus $5 \mu \mathrm{M}$ U0126 for six days. A: Representative Western blots. B-E: Western blot analysis of p-ERK (B), Runx2 (C), OPG (D) and Col-I (E) protein expression. The expression level of phosphorylated ERK was normalized to total ERK, and other osteogenic markers were normalized to GAPDH. Data represent the mean \pm SD (bars) of three independent experiments; ${ }^{*} \mathrm{P}<0.05,{ }^{* *} \mathrm{P}<0.01$ compared with cells cultured in differentiation medium containing $0 \mathrm{ng} / \mathrm{ml}$ Nell-1.

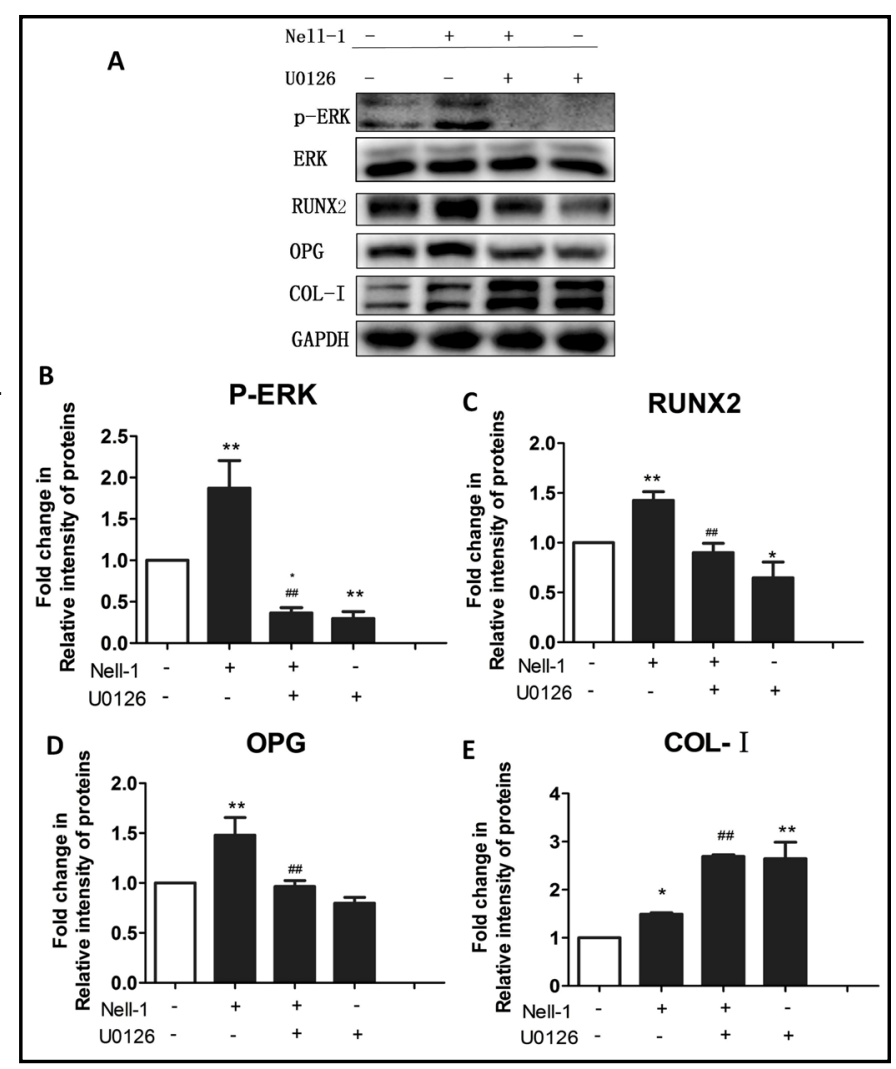

Fig. 10. Real-time PCR analysis of OCN (A), Runx2 (B), OPG (C), Osx (D), ALP (E) and Col-I (F) transcriptions in MC3T3-E1 pre-osteoblasts treated with $100 \mathrm{ng} / \mathrm{ml} \mathrm{Nell-1}$ and $5 \mu \mathrm{M}$ U0126 for 6 days. Data represent the mean \pm SD (bars) of three independent experiments; $\quad * \mathrm{P}<0.05, \quad{ }^{*} * \mathrm{P}<0.01$ compared with cells cultured in differentiation medium containing 0 ng/ml Nell-1.

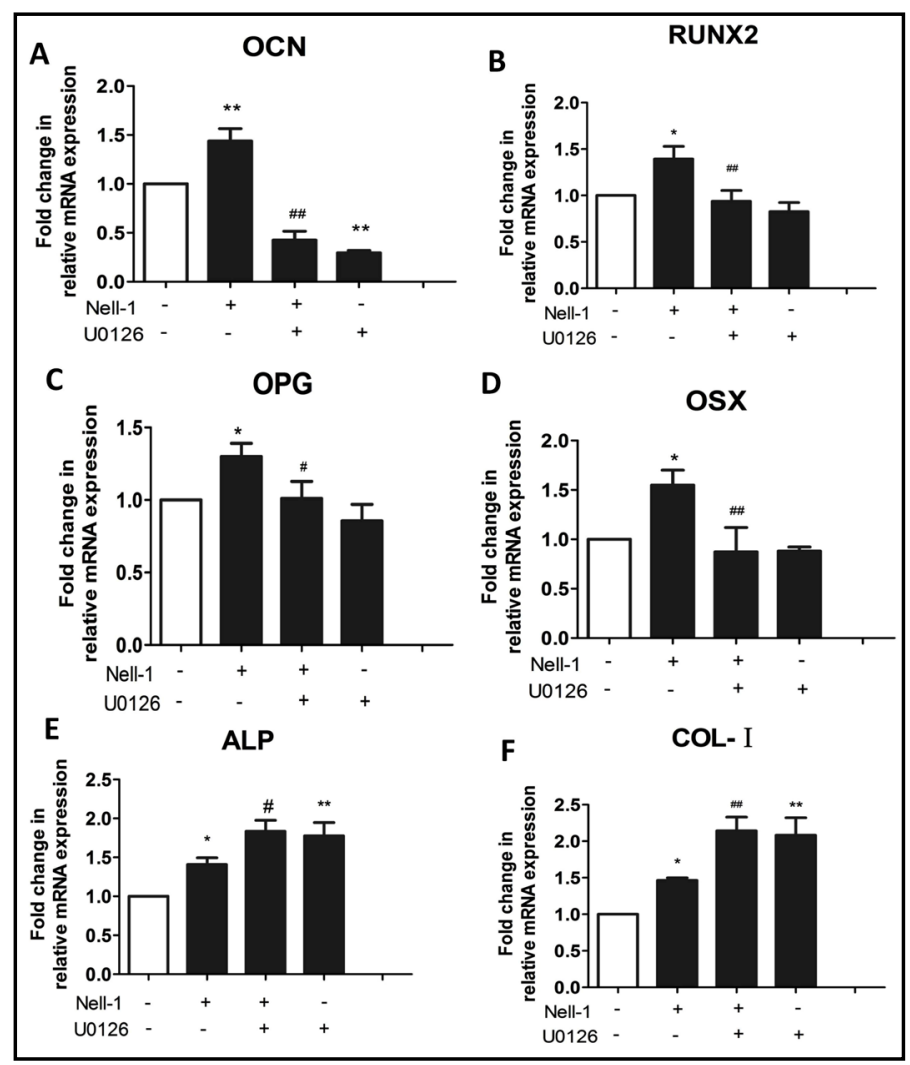




\section{Cellular Physiology Cell Physiol Biochem 2018;50:1522-1534 \\ \begin{tabular}{ll|l} 
DOl: 10.1159/000494651 & $\begin{array}{l}\text { O } 2018 \text { The Author(s). Published by S. Karger AG, Basel } \\
\text { www.karger.com/cpb }\end{array}$ \\
and Biochemistry Published online: 26 October 2018
\end{tabular}

whether U0126 can inhibit Nell-1-promoted ALP activity remained inconclusive (Fig. 8A).

The effect of U0126 pretreatment on OCN expression in MC3T3-E1 cells stimulated by Nell-1 for 18 days was then evaluated. Nell-1 significantly increased OCN expression, and U0126 effectively inhibited this effect, suggesting that U0126 can suppress Nell-1-promoted OCN expression by inhibiting ERK1/2 (Fig. 8B).For the differentiation markers Runx2, OPG and Col-Ion, WB assays revealed an upregulation of their expression levels in the MC3T3-E1 cells treated with Nell-1 for 6 days, and the upregulation of all markers except Col-I was suppressed by U0126 pretreatment. Similar to the findings regarding ALP activity, Col-I upregulation induced by Nell-I was further enhanced by U0126 (Fig. 9).

Finally, the mRNA expression of osteogenic markers in MC3T3-E1 cells treated with Nell-1 for 6 days were tested. Consistent with the WB results, the mRNA expression of all these markers was upregulated after Nell-1 treatment, and except for ALP and Col-I, transcriptional promotion by Nell-1 was inhibited by U0126 (Fig. 10).

\section{Discussion}

Titanium implants have been widely used in clinical settings due to their excellent biological properties and reliable and predictable performance [27, 28]. An ideal dental implant surface enhances the abilities of osteoblasts to secrete matrix proteins and deposit bone mineral for osteogenesis and facilitates osteointegration to withstand occlusal loading, which is pivotal for the implant's success [3]. In addition, a number of exogenous growth factors that can promote the early adhesion and differentiation of osteoblasts have gained increasing attention in the field of oral implantation [29]. Primary considerations in the development of dental implants include optimizing cell-tissue interactions, enhancing the bone response to the endosseous implant, and promoting the favorable behavior of bone tissue at the interface zone. For this purpose, pure Ti plates that have been polished, sandblasted and passivated can serve as ideal dental implants. B Groessner-Schreiber et al. proved that that porous or rough Ti implant surfaces may act as "natural" substrata that allow bone tissue to grow in direct contact with an implant and thereby strengthen clinical implant fixation [30]. In this study, scanning electron microscopy (SEM) showed that the Ti surface was rough and uneven and that pre-osteoblasts attached to the Ti surface for $24 \mathrm{~h}$ were completely spread out.

Nell-1 is osteochondral specific for inducing premature suture closure in human craniosynostosis and chondrogenic or osteoblastic differentiation [7, 8, 31-33]. When adenovirus-mediated (Ad-) Nell-1 and Ad-BMP2 were transferred to bone marrow stromal cells (BMSCs) from adult goats or injected into the intermuscular spaces of nude mice, Nell1 had a promotive effect on the osteogenic differentiation of BMSCs similar to that of bone morphogenetic protein-2 (BMP2) [34]. In addition, the co-expression of Nell-1 and apoptosisrelated protein 3 (APR3) enhanced OCN and BSP expression and matrix mineralization when Nell-1 and APR3 were assembled in the nuclear envelope of the human osteoblast cell lines Saos2 and U2OS [35]. IN particular, MC3T3-E1 pre-osteoblasts carrying the Nell-1 gene that overexpresses Nell-1 protein also have a higher expression of osteogenic markers compared with normal cells [16]. Matrix mineralization is enhanced in the MC3T3-E1 cells cultured in the presence of rhNell-1 or rhBMP-2 [36]. However, whether the addition of Nell-1 to culture medium can promote the osteogenic differentiation of pre-osteoblasts on the surface of $\mathrm{Ti}$ disks remains to be clarified.

Osteoblast differentiation includes two main processes: osteogenic commitment and osteogenic differentiation [37]. Osteogenic commitment is defined by the upregulation of a key transcription factor, Runx2 [37], while osteogenic differentiation is characterized by the expression of specific osteogenic proteins and transcription factors, such as ALP, OCN, COl-I, osteoprotegerin (OPG) and Osterix (Osx) [38-44]. In this study, ALP activity and OCN expression increased significantly in the Nell-1-treated cells on Ti surfaces compared with

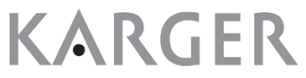




\section{Cellular Physiology Cell Physiol Biochem 2018;50:1522-1534 \\ \begin{tabular}{ll|l} 
DOl: 10.1159/000494651 & O 2018 The Author(s). Published by S. Karger AG, Basel \\
www.karger.com/cpb
\end{tabular} \\ Shen et al.: Nell-1 Enhances Osteogenic Differentiation via MAPK-ERK Signaling}

cells cultured in basal medium or Nell-1-free differentiation medium. The highest ALP activity and OCN expression were observed in the $100 \mathrm{ng} / \mathrm{ml}$ Nell-1 groups. The gene expressions of ALP and OCN were also improved in these groups. In addition, the expression of Runx2, Col-I, OPG and Osx was augmented by Nell-1 at both the gene and protein levels. Consistently, the expression of these osteogenic proteins and genes was highest in cells treated with Nell-1 at the concentration of $100 \mathrm{ng} / \mathrm{ml}$.

However, this study found that cell proliferation in the Nell-1-treated groups decreased over time compared with the control group, suggesting Nell-1 inhibited the proliferation of MC3T3-E1 cells on Ti surfaces. Nell-1 positively promoted osteogenesis but negatively affected the proliferation of pre-osteoblasts, indicating that Nell-1 has a stronger and more specific effect for eliciting osteoblast differentiation.

Osteogenic differentiation is a complex process involving numerous signaling cascades. Most of the exogenous growth factors involved in osteogenesis, such as BMP-2 and FGF, act on osteoblasts by binding to their cell-surface receptors to activate intracellular signaling pathways [45]. MAPKs, which are a group of serine/threonine-specific protein kinases expressed in all cell types, regulate various cellular processes, including proliferation, differentiation, migration, survival and gene expression [46]. The MAPK pathway is the most active pathway, and it can be activated by various growth factors [21]. The findings that MAPK induces the phosphorylation and stabilization of Runx2 suggest that MAPK-ERK signaling might have a positive effect on osteogenesis [22-24]. Therefore, to further elucidate the mechanisms underlying the effects of Nell-1, the MAPK-ERK signaling pathway was comprehensively investigated in the present study. The results showed that Nell-1 effectively activated the ERK and JNK pathways rather than the P38 pathway in pre-osteoblasts on Ti surfaces. Nakamura Y et al. found that Nell-1 mediated cell adhesion by binding to integrin receptors to activate ERK in MC3T3-E1 cells [47], confirming that Nell-1 can activate the ERK pathway in pre-osteoblasts. Interestingly, the selective activation of different MAPK pathways by Nell-1 depends on cell type [26]. Nell-1 effectively activates ERK in Saos-2 cells and all three major MAPKs in RFC cells, but activates ERK and JNK transiently in C3H10T1/2 cells and only JNK in C2C12 cells [14, 26]. In addition, compared with BMP2, Nell-1 does not affect the Smadl/5/8 pathway in any cell type [26]. It is noteworthy that OPN production could be reduced by the siRNA-mediated degradation of Ras through the inhibition of the ERK pathway [26]. Moreover, the JNK inhibitor SP600125 suppresses Nell-1-induced mineralization and intracellular phosphate accumulation in Saos-2 cells, while ERK1/2 and P38 inhibitors have no effect [48]. In this study, the expression of a series of osteogenic proteins and genes in pre-osteoblasts was significantly decreased by co-treatment with the ERK inhibitor U0126 and Nell-1. Nell-1 elevated the expression levels of OCN, Runx2, OPG and Osx, and its promotive effect could be reversed by U0126. The results suggest that the MAPK/ERK signaling pathways may be involved in the Nell-1-induced osteogenic differentiation of pre-osteoblasts on Ti surfaces.

Conversely, the results showed that ALP activity and the protein and gene expressions of Col-I were much higher in the cells treated with ERK inhibitor than in untreated cells. We speculated that U0126 may cause other effects in addition to suppressing the ERK signaling pathway, leading to an increase in ALP and Col-I. Previous research found that U0126 can activate the phosphorylation of P38 in BMSCs and increase ALP activity [49]. Consistently, this study confirmed that the expression of p-P38 in MC3T3-E1 cells could be up-regulated by U0126 treatment for $1 \mathrm{~h}$ (Fig. 11). P38 kinase is essential for the regulation of ALP expression during osteogenic differentiation [50]. Moreover, previous research found that p38 may be involved in the control of type I collagen expression [50]. Thus, it is very possible that U0126 may activate P38 or other pathways, leading to the upregulation of ALP and Col-I. Nevertheless, we could not rule out the possibility that the inhibition of a signaling pathway will lead to the inhibition or activation of other pathways due to the complex relationships of these pathways, and this possibility needs to be further explored. 


\section{Cellular Physiology Cell Physiol Biochem 2018;50:1522-1534 and Biochemistry \begin{tabular}{l|l} 
DOI: 10.1159/000494651 2018 The Author(s). Published by S. Karger AG, Basel \\
(c) 2018
\end{tabular}

\section{Conclusion}

The results suggest that Nell-1 promoted the osteogenic differentiation of pre-osteoblasts on a Ti surface. One of the mechanisms of Nell-1-mediated osteoblastic differentiation may be the activation of MAPK-ERK signaling, but the exact regulatory mechanisms need to be further explored. Nell-1 exerted a positive effect on osteogenic differentiation, which makes it a good candidate growth factor for clinical application to promote the osteointegration of dental implants.

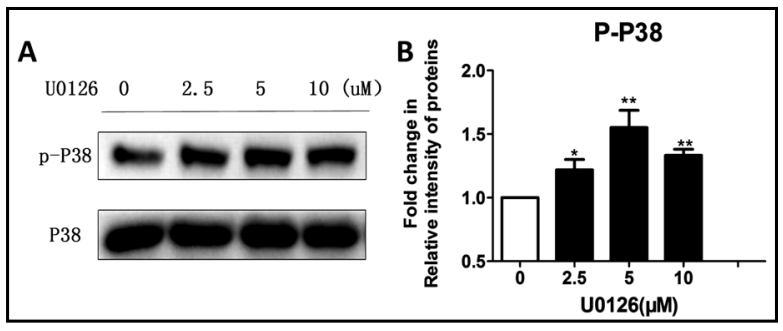

Fig. 11. Promotive effect of U0126 on P38 phosphorylation in MC3T3-E1 pre-osteoblasts. Cells on Ti surfaces were treated with U0126 (0-10 $\mu \mathrm{M})$ for $1 \mathrm{~h}$. A: Representative Western blots of p-P38 and P38. B: Western blot analysis of p-P38 expression. The expression level of phosphorylated P38 was normalized to that of total P38. Data represent the mean $\pm \mathrm{SD}$ (bars) of three independent experiments; ${ }^{*} \mathrm{P}<0.05,{ }^{* *} \mathrm{P}<0.01 *$ compared with cells cultured in differentiation medium containing $0 \mathrm{ng} / \mathrm{ml} \mathrm{U} 0126$.

\section{Acknowledgements}

This work was supported by the Wenzhou Science and Technology Bureau project (Y20140699), the Zhejiang Provincial Public Welfare technology application research project (2016C33179) and the general research project of Zhejiang Provincial Education Department (Y201533864).

This article does not contain any studies with human participants or animals performed by any of the authors.

\section{Disclosure Statement}

The authors declare no potential conflicts of interest with respect to the authorship and or publication of this article.

\section{References}

1 Barrere F, van der Valk CM, Meijer G, Dalmeijer RA, de Groot K, Layrolle P: Osteointegration of biomimetic apatite coating applied onto dense and porous metal implants in femurs of goats. J Biomed Mater Res B Appl Biomater 2003;67:655-665.

$>2$ Guo J, Padilla RJ, Ambrose W, De Kok IJ, Cooper LF: The effect of hydrofluoric acid treatment of TiO2 grit blasted titanium implants on adherent osteoblast gene expression in vitro and in vivo. Biomaterials 2007;28:5418-5425.

3 Kunzler TP, Drobek T, Schuler M, Spencer ND: Systematic study of osteoblast and fibroblast response to roughness by means of surface-morphology gradients. Biomaterials 2007;28:2175-2182.

-4 Park JW, Jang IS, Suh JY: Bone response to endosseous titanium implants surface-modified by blasting and chemical treatment: a histomorphometric study in the rabbit femur. J Biomed Mater Res B Appl Biomater 2008;84:400-407.

-5 Tavares MG, de Oliveira PT, Nanci A, Hawthorne AC, Rosa AL, Xavier SP: Treatment of a commercial, machined surface titanium implant with $\mathrm{H} 2 \mathrm{SO} 4 / \mathrm{H} 2 \mathrm{O} 2$ enhances contact osteogenesis. Clin Oral Implants Res 2007;18:452-458.

6 Esposito M, Coulthard P, Thomsen P, Worthington HV: The role of implant surface modifications, shape and material on the success of osseointegrated dental implants. A Cochrane systematic review. Eur J Prosthodont Restor Dent 2005;13:15-31. 


\section{Cellular Physiology Cell Physiol Biochem 2018;50:1522-1534

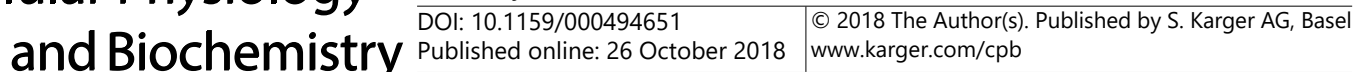

7 Ting K, Vastardis H, Mulliken JB, Soo C, Tieu A, Do H, Kwong E, Bertolami CN, Kawamoto H, Kuroda S, Longaker MT: Human NELL-1 expressed in unilateral coronal synostosis. J Bone Miner Res 1999;14:80-89.

-8 Zhang X, Kuroda Si, Carpenter D, Nishimura I, Soo C, Moats R, Iida K, Wisner E, Hu F-Y, Miao S, Beanes S, Dang C, Vastardis H, Longaker M, Tanizawa K, Kanayama N, Saito N, Ting K: Craniosynostosis in transgenic mice overexpressing Nell-1. J Clin Invest 2002;110:861-870.

-9 Desai J, Shannon ME, Johnson MD, Ruff DW, Hughes LA, Kerley MK, Carpenter DA, Johnson DK, Rinchik EM, Culiat CT: Nell1-deficient mice have reduced expression of extracellular matrix proteins causing cranial and vertebral defects. Hum Mol Genet 2006;15:1329-1341.

10 Shen J, James AW, Chung J, Lee K, Zhang JB, Ho S, Lee KS, Kim TM, Niimi T, Kuroda S, Ting K, Soo C: NELL-1 promotes cell adhesion and differentiation via Integrinbeta1. J Cell Biochem 2012;113:3620-3628.

-11 Zhang X, Ting K, Bessette CM, Culiat CT, Sung SJ, Lee H, Chen F, Shen J, Wang JJ, Kuroda S, Soo C: Nell-1, a key functional mediator of Runx2, partially rescues calvarial defects in Runx2(+/-) mice. J Bone Miner Res 2011;26:777-791.

12 Zhang X, Zara J, Siu RK, Ting K, Soo C: The role of NELL-1, a growth factor associated with craniosynostosis, in promoting bone regeneration. J Dent Res 2010;89:865-878.

13 Siu RK, Lu SS, Li W, Whang J, McNeill G, Zhang X, Wu BM, Turner AS, Seim HB, 3rd, Hoang P, Wang JC, Gertzman AA, Ting K, Soo C: Nell-1 protein promotes bone formation in a sheep spinal fusion model. Tissue Eng Part A 2011;17:1123-1135.

14 Cowan CM, Jiang X, Hsu T, Soo C, Zhang B, Wang JZ, Kuroda S, Wu B, Zhang Z, Zhang X, Ting K: Synergistic effects of Nell-1 and BMP-2 on the osteogenic differentiation of myoblasts. J Bone Miner Res 2007;22:918930.

15 Aghaloo T, Cowan CM, Zhang X, Freymiller E, Soo C, Wu B, Ting K, Zhang Z: The effect of NELL1 and bone morphogenetic protein-2 on calvarial bone regeneration. J Oral Maxillofac Surg 2010;68:300-308.

-16 Aghaloo T, Cowan CM, Chou YF, Zhang X, Lee H, Miao S, Hong N, Kuroda S, Wu B, Ting K, Soo C: Nell-1induced bone regeneration in calvarial defects. Am J Pathol 2006;169:903-915.

17 Li W, Lee M, Whang J, Siu RK, Zhang X, Liu C, Wu BM, Wang JC, Ting K, Soo C: Delivery of lyophilized Nell-1 in a rat spinal fusion model. Tissue Eng Part A 2010;16:2861-2870.

-18 Li W, Zara JN, Siu RK, Lee M, Aghaloo T, Zhang X, Wu BM, Gertzman AA, Ting K, Soo C: Nell-1 enhances bone regeneration in a rat critical-sized femoral segmental defect model. Plast Reconstr Surg 2011;127:580-587.

19 Lu SS, Zhang X, Soo C, Hsu T, Napoli A, Aghaloo T, Wu BM, Tsou P, Ting K, Wang JC: The osteoinductive properties of Nell-1 in a rat spinal fusion model. Spine J 2007;7:50-60.

20 Seger R, Krebs EG: The MAPK signaling cascade. FASEB J 1995;9:726-735.

21 Lee KS, Hong SH, Bae SC: Both the Smad and p38 MAPK pathways play a crucial role in Runx2 expression following induction by transforming growth factor-beta and bone morphogenetic protein. Oncogene 2002;21:7156-7163.

22 Jaiswal RK, Jaiswal N, Bruder SP, Mbalaviele G, Marshak DR, Pittenger MF: Adult human mesenchymal stem cell differentiation to the osteogenic or adipogenic lineage is regulated by mitogen-activated protein kinase. J Biol Chem 2000;275:9645-9652.

23 Park OJ, Kim HJ, Woo KM, Baek JH, Ryoo HM: FGF2-activated ERK mitogen-activated protein kinase enhances Runx2 acetylation and stabilization. J Biol Chem 2010;285:3568-3574.

-24 Xiao G, Jiang D, Gopalakrishnan R, Franceschi RT: Fibroblast growth factor 2 induction of the osteocalcin gene requires MAPK activity and phosphorylation of the osteoblast transcription factor, Cbfa1/Runx2. J Biol Chem 2002;277:36181-36187.

25 Chang F, Steelman LS, Lee JT, Shelton JG, Navolanic PM, Blalock WL, Franklin RA, McCubrey JA: Signal transduction mediated by the Ras/Raf/MEK/ERK pathway from cytokine receptors to transcription factors: potential targeting for therapeutic intervention. Leukemia 2003;17:1263-1293.

26 Bokui N, Otani T, Igarashi K, Kaku J, Oda M, Nagaoka T, Seno M, Tatematsu K, Okajima T, Matsuzaki T, Ting K, Tanizawa K, Kuroda S: Involvement of MAPK signaling molecules and Runx2 in the NELL1-induced osteoblastic differentiation. FEBS Lett 2008;582:365-371.

27 Kirmanidou Y, Sidira M, Drosou ME, Bennani V, Bakopoulou A, Tsouknidas A, Michailidis N, Michalakis K: New Ti-Alloys and Surface Modifications to Improve the Mechanical Properties and the Biological Response to Orthopedic and Dental Implants: A Review. Biomed Res Int 2016;2016:2908570.

-28 Gaviria L, Salcido JP, Guda T, Ong JL: Current trends in dental implants. J Korean Assoc Oral Maxillofac Surg 2014;40:50-60. 


\section{Cellular Physiology Cell Physiol Biochem 2018;50:1522-1534 \begin{tabular}{ll|l} 
DOl: 10.1159/000494651 & $\begin{array}{l}\text { O 2018 The Author(s). Published by S. Karger AG, Basel } \\
\text { www.karger.com/cpb }\end{array}$
\end{tabular}

-29 Schneider GB, Perinpanayagam H, Clegg M, Zaharias R, Seabold D, Keller J, Stanford C: Implant surface roughness affects osteoblast gene expression. J Dent Res 2003;82:372-376.

-30 Groessner-Schreiber B, Tuan RS: Enhanced extracellular matrix production and mineralization by osteoblasts cultured on titanium surfaces in vitro. J Cell Sci 1992;101:209-217.

31 Cowan CM, Cheng S, Ting K, Soo C, Walder B, Wu B, Kuroda S, Zhang X: Nell-1 induced bone formation within the distracted intermaxillary suture. Bone 2006;38:48-58.

-32 Zhang X, Carpenter D, Bokui N, Soo C, Miao S, Truong T, Wu B, Chen I, Vastardis H, Tanizawa K, Kuroda S, Ting K: Overexpression of Nell-1, a craniosynostosis-associated gene, induces apoptosis in osteoblasts during craniofacial development. J Bone Miner Res 2003;18:2126-2134.

-33 Zhang X, Cowan CM, Jiang X, Soo C, Miao S, Carpenter D, Wu B, Kuroda S, Ting K: Nell-1 induces acrania-like cranioskeletal deformities during mouse embryonic development. Lab Invest 2006;86:633-644.

34 Aghaloo T, Jiang X, Soo C, Zhang Z, Zhang X, Hu J, Pan H, Hsu T, Wu B, Ting K, Zhang X: A study of the role of nell-1 gene modified goat bone marrow stromal cells in promoting new bone formation. Mol Ther 2007;15:1872-1880.

-35 Zou X, Shen J, Chen F, Ting K, Zheng Z, Pang S, Zara JN, Adams JS, Soo C, Zhang X: NELL-1 binds to APR3 affecting human osteoblast proliferation and differentiation. FEBS Lett 2011;585:2410-2418.

-36 Cowan CM, Zhang X, James AW, Kim TM, Sun N, Wu B, Ting K, Soo C: NELL-1 increases pre-osteoblast mineralization using both phosphate transporter Pit1 and Pit2. Biochem Biophys Res Commun 2012;422:351-357.

-37 Xu J, Li Z, Hou Y, Fang W: Potential mechanisms underlying the Runx2 induced osteogenesis of bone marrow mesenchymal stem cells. Am J Transl Res 2015;7:2527-2535.

38 Beck GR, Jr., Zerler B, Moran E: Phosphate is a specific signal for induction of osteopontin gene expression. Proceedings of the National Academy of Sciences of the United States of America 2000;97:8352-8357.

39 Mark MP, Butler WT, Prince CW, Finkelman RD, Ruch JV: Developmental expression of 44-kDa bone phosphoprotein (osteopontin) and bone gamma-carboxyglutamic acid (Gla)-containing protein (osteocalcin) in calcifying tissues of rat. Differentiation 1988;37:123-136.

40 Uchihashi K, Aoki S, Matsunobu A, Toda S: Osteoblast migration into type I collagen gel and differentiation to osteocyte-like cells within a self-produced mineralized matrix: a novel system for analyzing differentiation from osteoblast to osteocyte. Bone 2013;52:102-110.

41 Klejna K, Naumnik B, Gasowska K, Mysliwiec M: OPG/RANK/RANKL signaling system and its significance in nephrology. Folia Histochem Cytobiol 2009;47:199-206.

42 Komori T: Regulation of osteoblast differentiation by Runx2. Adv Exp Med Biol 2010;658:43-49.

43 Myllyharju J, Kivirikko KI: Collagens, modifying enzymes and their mutations in humans, flies and worms. Trends Genet 2004;20:33-43.

44 Nakashima K, Zhou X, Kunkel G, Zhang Z, Deng JM, Behringer RR, de Crombrugghe B: The novel zinc fingercontaining transcription factor osterix is required for osteoblast differentiation and bone formation. Cell 2002;108:17-29.

45 Hughes FJ, Turner W, Belibasakis G, Martuscelli G: Effects of growth factors and cytokines on osteoblast differentiation. Periodontol 2000. 2006;41:48-72.

-46 Zhao Y, Song T, Wang W, Wang J, He J, Wu N, Tang M, He B, Luo J: P38 and ERK1/2 MAPKs act in opposition to regulate BMP9-induced osteogenic differentiation of mesenchymal progenitor cells. PLoS One 2012;7:e43383.

47 Nakamura Y, Hasebe A, Takahashi K, Iijima M, Yoshimoto N, Maturana AD, Ting K, Kuroda S, Niimi T: Oligomerization-induced conformational change in the C-terminal region of Nel-like molecule 1 (NELL1) protein is necessary for the efficient mediation of murine MC3T3-E1 cell adhesion and spreading. J Biol Chem 2014;289:9781-9794.

48 Chen F, Walder B, James AW, Soofer DE, Soo C, Ting K, Zhang X: NELL-1-dependent mineralisation of Saos-2 human osteosarcoma cells is mediated via c-Jun N-terminal kinase pathway activation. Int Orthop 2012;36:2181-2187.

49 Doan TKP, Park KS, Kim HK, Park DS, Kim JH, Yoon TR: Inhibition of JNK and ERK pathways by SP600125and U0126-enhanced osteogenic differentiation of bone marrow stromal cells. Tissue Eng Regen Med 2012;9:283-294.

-50 Suzuki A, Guicheux J, Palmer G, Miura Y, Oiso Y, Bonjour JP, Caverzasio J: Evidence for a role of p38 MAP kinase in expression of alkaline phosphatase during osteoblastic cell differentiation. Bone 2002;30:91-98. 